the use of the life should be economical. Let me, in that point of view, invite you to compare, or rather to contrast with one another, those two sorts of experiments from which we have to get our knowledge of the causes of diseases. The commercial experiments which illustrated the dangerousness of sewage-polluted water supplies cost many thousands of human lives ; the scientific experiments which, with infinitely more exactitude, justified a presumption of dangerousness cost the lives of fourteen mice."

We see, then, that in one way or another experiment must form the basis on which medical science is to be built up. The question for us to decide is, "Shall these experiments be few, carefully planned, conclusive, economical of animal life, or shall they be numerous, accidental, vague and wasteful of human life?" I think in settling this question we may safely take for our guide the words of Him who said, "Ye are of more value than many sparrows."

H. P. Bowditch.

\section{THE DECORATIVE ART OF THE INDIANS OF THE NORTH PACIFIC COAST.}

IT is well known that the native tribes of the North Pacific coast of America ornament their implements with conventionalized representations of animals. The tribes of this region are divided in clans which have animal totems, and it is generally assumed that the carvings represent the totem of the owner of the implement. This view is apparently sustained by the extensive use of the totem as a crest. It is represented on 'totem poles' or heraldic columns, on the fronts of houses, on canoes, on the handles of spoons, and on a variety of objects.

It can be shown, however, that by no means all the carvings made by the natives of this region have this meaning, A collection of data made in a number of museums show that certain objects are preferably ornamented with representations of certain animals, and in many cases an intimate connection exists between the use to which the object is put and its design.

This is very evident in the case of the fish club, which is used for despatching halibut and other fish before they are hauled into the canoe. Almost all the clubs that I have seen represent the sea lion or the killer whale, the two sea animals which are most feared by the Indians, and which kill those animals that are to be killed by means of the club. The idea of giving the club the design of the sea lion or killer whale is therefore rather to give it a form appropriate to its function and perhaps secondarily to give it by means of its form great efficiency. This view is corroborated by the following incident which occurs in several tales: A person throws his fish club overboard and it swims away and kills seals and other sea animals, cuts the ice and performs other feats taking the shape of a sea lion or of a killer whale. Here also belongs the belief recorded by Alexander Mackenzie (Trans. Roy. Soc. of Canada, 1891, Sec. II., p. 51): "The Haida firmly believe, if overtaken by night at sea and reduced to sleep in their canoes, that by allowing such a club to float beside the canoe attached to a line it has the property of scaring away whales and other monsters of the deep which might otherwise harm them."

Here is another instance in which I find a close relation between the function of the object and its design. Small grease dishes have almost invariably the shape of the seal or sometimes that of the sea lion, that is, of those animals which furnish a vast amount of blubber. Grease of sea animals is considered as the sign of wealth. In many tales abundance of food is described by saying that the sea near the houses was covered with the grease of seal, sea lion and whales. Thus the form of the seal seems to symbolize affluence. 
Other grease dishes and food dishes have the form of canoes, and here $I$ believe a similar idea has given rise to the form. The canoe symbolizes that a canoe load of food is presented to the guests, and that this view is probably correct is indicated by the fact that in his speeches the host often refers to the canoe filled with food which he gives to his guests. The canoe form is often modified, and a whole series of types can be established forming the transition between canoe dishes and ordinary trays. Dishes of this sort always bear a conventionalized face at each short end, while the middle part is not decorated. This is analogous to the style of the decoration of the canoe. The design represents almost always the hawk. I am not certain what has given origin to the prevalence of this design. On the whole the decoration of the canoe is totemistic. It may be that it is only the peculiar manner in which the beak of the hawk is represented which has given rise to the prevalence of this decoration. The upper jaw of the hawk is always shown so that its point reaches the lower jaw and turns back into the mouth. When painted or carved in front view the beak is indicated by a narrow wedge-shaped strip in the middle of the face, the point of which touches the lower margin of the chin. The sharp bow and stern of a canoe with a profile of a face on each side, when represented on a level or slightly rounded surface, would assume the same shape. Therefore, it may be that originally the middle line was not the beak of the hawk, but the foreshortened bow or stern of the canoe. This decoration is so uniform that the explanation given here seems to me very probable.

On halibut hooks we find very often decorations representing the squid. The reason for selecting this motive must be looked for in the fact that the squid is used for baiting the hooks.

I am not quite certain if the decoration of armor and weapons is totemistic or symbolic. Remarkably many helmets represent the sea lion, many daggers the bear, eagle, wolf and raven, while I have not seen one that represents the killer whale, although it is one of the ornaments that are most frequently shown on totemistic designs.

I presume this phenomenon may be accounted for by a consideration of the ease with which the conventionalized forms lend themselves to decorating certain parts of implements. It is difficult to imagine how the killer whale should be represented on the handle of a dagger without impairing its usefulness. On the other hand, the long thin handles of ladles made of the horn of the big horn sheep generally terminate with the head of a raven or of a crane, the beak being the end of the handle. This form was evidently suggested by the slender tip of the horn, which is easily carved in this shape. The same seems to be true in the cases of lances or knives, the blades of which are represented as the long protruding tongues of animals, but it may be that in this case there is a complex action of a belief in the supernatural power of the tongue and in the suggestions which the decorator received from the shape of the object he desired to decorate.

To sum up, it seems that there are a great number of cases of decoration which cannot be considered totemistic, but which are either symbolic or suggested by the shape of the object to be decorated. It seems likely that totemism was the most powerful incentive in developing the art of the natives of the North Pacific coast; but the desire to decorate in certain conventional forms once established, these forms were applied in cases in which there was no reason and no intention of using the totemistic mark. The thoughts of the artist were influenced by considerations foreign to the idea of totemism. This is one of the numerous ethnological pheno- 
mena which, although apparently simple, cannot be explained psychologically from a single cause but are due to several factors. Franz Boas.

\section{RECENT HYDROGRAPHIC EXAMINATIONS IN} THE APPALACHIAN AREA.*

THE systematic study of the discharges of the streams of the United States has, with one or two exceptions, been undertaken only in recent years. The expense and time required for such investigations prohibits the private engineer from undertaking them, and they can be carried on, therefore, only by large corporations, municipal or State authorities, or by the National Government. Among the most valuable contributions to this branch of engineering have been investigations ordered by the cities of Boston and New York in connection with the study of their water supply. The Sudbury records for Boston supply data since 1875 and those of the Croton for New York since 1868. These are on relatively small basins, however, the former having a drainage area of 78 square miles and the latter 353 square miles.

The army engineers in connection with the improvement of the Connecticut river carried on systematic observations of the discharge of that river at Hartford, Conn., from 1871 to 1879 , inclusive, and from that period to the present time the Holyoke Water Power Company have continued the observations. The company in charge of the water powers at Lowell and Lawrence, Mass., on the Merrimac river, have carried on measurements of discharges for over fifty years, but their engineers have published little information. The State of New Jersey, in the interest of her water powers, and the city of Philadelphia, for the future de-

\footnotetext{
* Read before the National Geographic Society, November 15,1895 , by F. H. Newell, U. S. Geological Survey, Washington, D. C.
}

velopment of her water supply, commenced seven and nine years ago, respectively, the study of certain drainage basins, but they are also relatively small areas. The U.S. Geological Survey, in May, 1891, established a gauging station on the Potomac at Chain Bridge, D. C., for the measurement of the discharge of the river at that place. It was started somewhat as an experimental station, the time given to it being that which could be spared by hydrographers from office work. Gauge height observations were continued until the end of 1893 , when, on account of lack of time and of funds, they were discontined.

It has for years been the desire of the hydrographers of this survey to make a thorough and detailed study of the drainage system of one large river, to measure its different tributaries, and to study the relation of their discharges to that of the entire system. An opportunity was afforded for the development of this plan in the spring of 1894, and the Potomac basin was chosen as being convenient of access and as typical of large areas along Appalachian range. Gauging stations were established as follows: First, on the North Branch at Cumberland, Md.; second, on the South Branch three miles above Springfield, W. Va. ; third, at Dam No. 6, ten miles above Hancock, Md. ; fourth, one on the Shenandoah at Millville, W. Va., five miles above its mouth, and fifth, one on the main river at Point of Rocks, Md. Daily observations of the height of the river at Chain Bridge were also resumed, but measurements of the discharge were not made, as it was found that this point was not a favorable location for such measurements. In high water the velocity is too great, owing to the restricted channel, and in low water the daily tides introduce errors that are hard to eliminate. Work was actively prosecuted in this basin during the past spring, and a sufficient number of gaugings were made to construct 